\title{
Toxicity of Zinc on Growth of an Aquatic Macrophyte, Ipomoea aquatica Forsk
}

\section{LAITONJAM BEDABATI CHANU and ABHIK GUPTA*}

Department of Ecology and Environmental Science, Assam University, Silchar-788011, Assam, India.

http://dx.doi.org/10.12944/CWE.11.1.27

(Received: March 28, 2016; Accepted: April 15, 2016)

\begin{abstract}
The effects of different concentrations of $\mathrm{Zn}$ on growth of an aquatic macrophyte, Ipomoea aquatica Forsk. were studied. Fresh weight, dry weight, shoot length, root length, number of nodes, development of leaves, and chlorophyll and carotene contents were the different growth parameters considered. Toxicity symptoms like browning and decaying of roots could be observed in plants treated at $22.7 \mathrm{mg} \mathrm{L}^{-1} \mathrm{Zn}$ as early as $3^{\text {rd }}$ day of experiment while yellowing of older leaves appeared during the later period of exposure. High concentration of $\mathrm{Zn}\left(12.71-22.7 \mathrm{mg} \mathrm{L}^{-1}\right)$ significantly inhibited the growth of plant while lower $\mathrm{Zn}$ concentrations up to $4.09 \mathrm{mg} \mathrm{L}^{-1}$ enhanced its growth. However, at $7.26 \mathrm{mg} \mathrm{L}^{-1} \mathrm{Zn}$ the chlorophyll as well as total carotene content in leaf of $I$. aquatica were significantly reduced from that in control on $5^{\text {th }}$ day of exposure and subsequently the reduction was observed in lower concentrations. Thus, I. aquatica can be employed in biomonitoring of $\mathrm{Zn}$ polluted aquatic ecosystems using root browning, root and shoot growth inhibition, and chlorophyll and total carotene contents as sensitive biomarkers.
\end{abstract}

Keywords: Aquatic ecosystems, Biomonitoring, Carotene, Chlorophyll, Root browning.

\section{INTRODUCTION}

Natural environment, particularly the aquatic ecosystem is being disturbed by anthropogenic activities with rise in industrialization and urbanization. The decline in water quality of fresh water systems threatens its sustainability and has become one of the major environmental issues. The current scenario of Indian freshwater resources has been studied by many workers and appealed for their management as environmental problems. The increased concentrations of heavy metals in receiving water, especially lakes and rivers worsened the situation and threatened the biological components through bioaccumulation along the food chain and ultimately affect human being as well ${ }^{1-5}$.

$\mathrm{Zn}$ which is an essential micronutrient associated with metabolic activities in organisms can turn toxic at higher concentrations. Its concentration in various Indian aquatic ecosystems has reached alarming levels as reported by a number of scientific studies $^{4,6-9}$. The main sources of $\mathrm{Zn}$ in fresh water ecosystems includes effluents from electroplating industries, smelting and refining, mining, paper industries, domestic sewage and agricultural runoff ${ }^{10}$. The immersion of idols and tazias is also one of the major reasons for increase level of $Z n$ in lakes and rivers all over India ${ }^{11-13}$. $\mathrm{Zn}$ is one of the major constituents of paints for decorating both idols and tazias, and it has been reported that the number of idol immersion is being increased each year, which could increase load of heavy metals ${ }^{14}$.

Although $\mathrm{Zn}$ is a micronutrient, it becomes hazardous at high levels ${ }^{15}$. The growing concern in environmental aspects as well as the narrow window between its essentiality and toxicity ${ }^{16}$ has generated interest in studying its effects on aquatic plants which play an important role in ecosystem functioning. In addition, a regular testing of $\mathrm{Zn}$ pollution in fresh water is required in the Indian context. Thus, 
the present study was carried out with the aim of exploring the potential of an aquatic macrophyte, Ipomoea aquatica Forsk. to be used in biomonitoring and phytotoxicity studies. This plant was selected on the basis of its geographical distribution, availability and adaptability. It is widely distributed not only in India, but in the entire South, South East, and East Asia ${ }^{17}$ and well adapted to wide range of habitats. It is also reported to be grown in other parts of the world like Africa, Australia and United States of America (Austin, 2007) ${ }^{18}$. Further, it is perennial and mostly grows in moist soil, inundated floodplains, ditches, ponds, canals and sluggish rivers ${ }^{19}$ and easy to cultivate due to its ability to proliferate by fragmentation, and produce adventitious roots and lateral branches that bear flowers and leaves, from its nodes ${ }^{20}$.

A number of studies have been conducted on $\mathrm{Zn}$ toxicity using aquatic plants. Growth inhibition was observed in Eichhornia crassipes ${ }^{21}$, Lemna gibba $^{22}$, Phragmites australis ${ }^{23}$, Iris psuedacarus ${ }^{24}$,
Spirodela polyrhiza ${ }^{25}$ and Salvinia natans ${ }^{26}$. Another study reported the inhibition of growth induced by $\mathrm{Zn}$ stress in three aquatic macrophytes viz. Lemna minor, Elodea canadensis and Leptodictyum riparium, where L. riparium turned out to be the most resistant species with $50 \%$ growth inhibition at 100 $\mu \mathrm{M} \mathrm{Zn}{ }^{27}$. In contrast to this, studies on $\mathrm{Zn}$ toxicity to $A$. aquatica is scarce. This study was, therefore, taken up to understand and assess the toxic effects of $\mathrm{Zn}$ on this aquatic macrophyte.

\section{MATERIALS AND METHODS}

Ipomoea aquatica Forsk. was collected from uncontaminated ponds of Irongmara area in Cachar district, Assam, India, and washed with tap water. Stock cultures were grown following standard method $^{28}$. The plants were grown in hydroponic tubs till new branches developed. These new branches were cut and planted in pots containing soil flooded with $50 \%$ Hoagland nutrient media. The $\mathrm{pH}$ of nutrient media was adjusted at the range of 5.8-

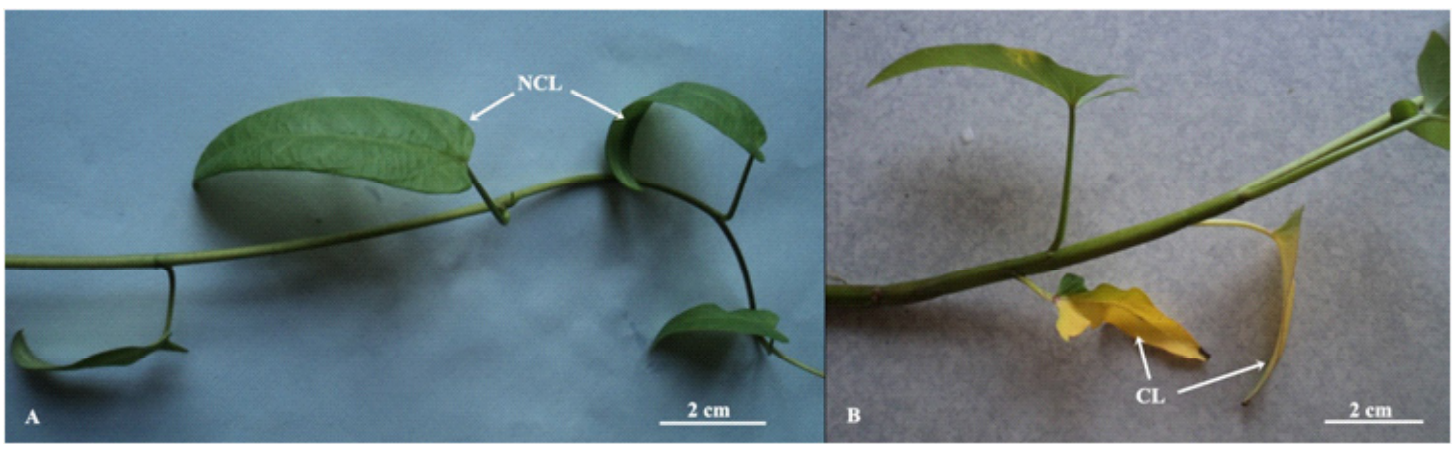

Fig.1: $\mathrm{Zn}$ induced change in appearance of leaf in I. aquatica; A- Non chlorotic leaf (NCL) of control; B- Chlorotic leaf (CL) of plant treated at $22.7 \mathrm{mg} \mathrm{L}^{-1} \mathrm{Zn}$

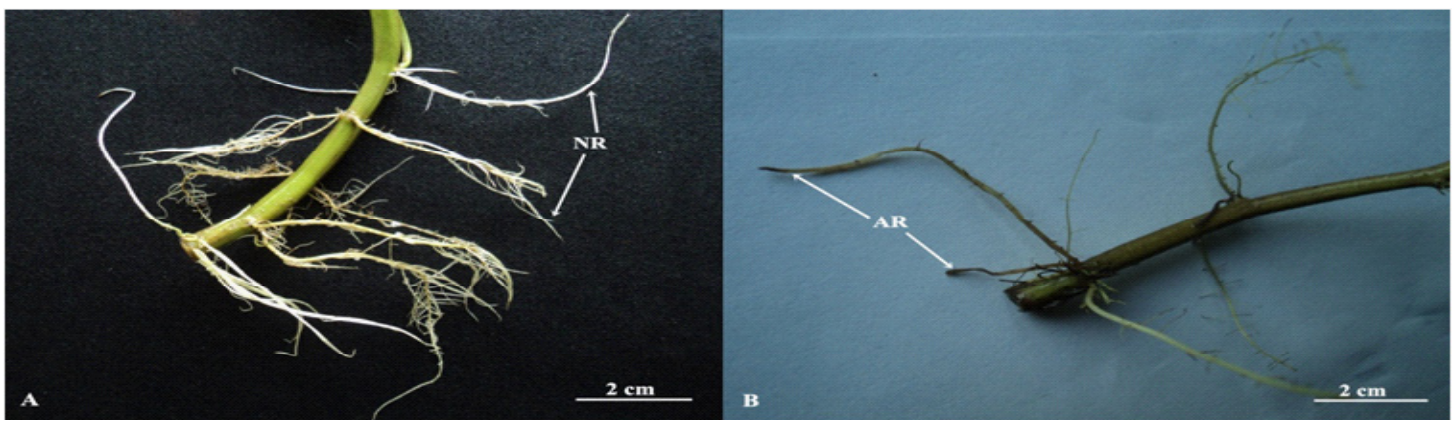

Fig. 2: Zn induced darkening of root in I. aquatica; A- Normal root (NR) of control; B- Affected root (AR) of plant treated at $22.7 \mathrm{mg} \mathrm{L}^{-1} \mathrm{Zn}$ 
6.2. Healthy and fully grown shoots of similar shoot height were cut from the same mother plant, washed with tap water and acclimatized in $50 \%$ Hoagland nutrient media for one week at $25-27^{\circ} \mathrm{C}, 12 \mathrm{~h}$ light with an intensity of $100-120 \mathrm{mmol}^{-2} \mathrm{~s}^{-1}$ and $12 \mathrm{~h}$ dark periods. These acclimatized plants were exposed to half strength Hoagland nutrient media added with graded concentrations of $\mathrm{Zn}$ as $\mathrm{ZnSO}_{4} \cdot 7 \mathrm{H}_{2} \mathrm{O}$ (actual Zn concentrations: $0.23 \mathrm{mg} \mathrm{L}^{-1}, 2.27 \mathrm{mg} \mathrm{L}^{-1}, 4.09$ $\mathrm{mg} \mathrm{L}^{-1}, 7.26 \mathrm{mg} \mathrm{L}^{-1}, 12.71 \mathrm{mg} \mathrm{L}^{-1}$ and $22.7 \mathrm{mg} \mathrm{L}^{-1}$ ) for 15 days. Plants grown in $50 \%$ Hoagland media without added $\mathrm{Zn}$ served as control. Water loss due to evaporation or transpiration was compensated by renewal of solutions every week. At the termination of the experiment on $15^{\text {th }}$ day all control and $\mathrm{Zn}$ treated plants were removed, washed with distilled water, and softly blotted to remove excess water before fresh weight of the plants, their root length and lateral roots, and leaf area were measured. This was followed by drying in hot air oven at $60^{\circ} \mathrm{C}$ till constant weight. Other growth parameters such as shoot length, new leaves, and number of nodes were measured at 3 day intervals. The percentage of primary roots bearing lateral roots (PRL \%), and the ratio of lateral roots (LR) to the number of primary roots bearing lateral roots $(P R L)$ was calculated. All these data were also obtained before the plants were exposed to $\mathrm{Zn}$. Leaf area was measured by using ImageJ (http://imagej.nih.gov/ij/) software. All leaves were neatly clipped at their petioles and properly spread to take the image of the entire leaf area. Toxicity symptoms on leaf and root, such as darkening of roots and appearance of chlorosis were noted during the experiment. For chlorophyll

\section{Table 1: Appearance of darkening of roots in $I$. aquatica on exposure to graded concentrations of $\mathrm{Zn}(\mathrm{n}=5)$}

\begin{tabular}{|c|c|c|c|c|c|}
\hline \multirow{2}{*}{$\begin{array}{l}\text { Zn } \\
\text { Conc. } \\
\left(\mathrm{mg} \mathrm{L}^{-1}\right)\end{array}$} & \multicolumn{5}{|c|}{ Number of plants with darkened roots } \\
\hline & $\begin{array}{c}\text { Day } \\
3\end{array}$ & $\begin{array}{c}\text { Day } \\
6\end{array}$ & $\begin{array}{c}\text { Day } \\
9\end{array}$ & $\begin{array}{c}\text { Day } \\
12\end{array}$ & $\begin{array}{c}\text { Day } \\
15\end{array}$ \\
\hline 0.23 & 0 & 0 & 0 & 1 & 1 \\
\hline 2.27 & 0 & 0 & 0 & 1 & 1 \\
\hline 4.09 & 0 & 1 & 2 & 2 & 2 \\
\hline 7.26 & 0 & 1 & 2 & 3 & 3 \\
\hline 12.71 & 1 & 2 & 2 & 4 & 5 \\
\hline 22.7 & 3 & 5 & 5 & 5 & 5 \\
\hline
\end{tabular}

estimation, fresh leaf was homogenized with $80 \%$ acetone, centrifuged, and the absorbance of the supernatant was taken at 662,645 , and $470 \mathrm{~nm}$ for chlorophyll a (chl a), chlorophyll b (chl b) and total carotene, respectively, in a spectrophotometer. The concentrations of these pigments were calculated following standard formula ${ }^{[29]}$ with the extraction solution used as blank.

Statistical significance of differences among the data sets was determined with One-way ANOVA, with multiple comparisons made by Tukey test. All tests were done using SPSS 20 software for Windows.

\section{RESULTS AND DISCUSSION}

Plants at all concentrations of $\mathrm{Zn}$ could survive the total exposure period of 15 days, although some toxicity symptoms were encountered in plants exposed to higher concentrations of $\mathrm{Zn}$. Thus the survival pattern of the plant reflected its tolerance capacity up to $\mathrm{Zn}$ concentrations of $22.7 \mathrm{mg} \mathrm{L}^{-1}$. Among aquatic macrophytes, Typha agustifolia and Colocasia esculenta were found to be the most tolerant plants to heavy metals ${ }^{[30]}$. These two plants did not show any significant toxicity symptoms when they were grown in sediment contaminated with $\mathrm{Zn}$ concentration of $363 \mathrm{mg} \mathrm{kg}^{-1}$. Eichhornia crassipes when exposed to $20 \mathrm{mg} \mathrm{L}^{-1} \mathrm{Zn}$ did not show any morphological symptom of toxicity ${ }^{[31]}$. The present study revealed that plants treated at $22.7 \mathrm{mg} \mathrm{L}^{-1}$ showed yellowing of older leaves (Fig. 1), while significant blackening of root tips occurred at 22.7 $\mathrm{mg} \mathrm{L}^{-1} \mathrm{Zn}$ on the $3^{\text {rd }}$ day of exposure (Fig. 2).

Blackening of root tips was also observed in plants treated at other concentrations with longer exposure time (Table 1). One way ANOVA showed significant reduction in length of PR at $7.26-22.7$ $\mathrm{mg} \mathrm{L}^{-1} \mathrm{Zn}$ (Table 1) which might be correlated to gradual decaying of roots along the length. $Z n$ at 200 $\mu \mathrm{g} \mathrm{ml}^{-1}$ reduced root biomass in Iris psuedacorus ${ }^{24}$. However, symptoms like blackening and decaying of roots were not reported, although plants exposed to other heavy metals like $\mathrm{Cd}$ showed browning of root tips ${ }^{32}$. Dark root tips in Vicia faba ${ }^{33}$ and cell death in root tissues of Talinum triangulare ${ }^{34}$ were also reported due to oxidative stress induced by $\mathrm{Pb}$ accumulation. Thus, these symptoms of toxicity in 
roots can be used as a tool in biomonitoring of $\mathrm{Zn}$ pollution in water. The suppression of development of new PR led to a significant reduction in the PRL $\%$ as well as lateral roots in plants treated at 12.71 - $22.7 \mathrm{mg} \mathrm{L}^{-1} \mathrm{Zn}$ (Table 2). A significant reduction at $p<0.05$ in LR: PRL was also observed in plants treated with $7.26-22.7 \mathrm{mg} \mathrm{L}^{-1} \mathrm{Zn}$ at the end of 15 day exposure as revealed by one way ANOVA and multiple comparisons by Tukey test (Table 2). Zn at concentrations of 0.23 and $2.27 \mathrm{mg} \mathrm{L}^{-1}$, on the other hand, enhanced growth of roots in I. aquatica.

Despite the toxic symptoms exhibited by I. aquatica, growth in terms of fresh weight and

Table 2: Effects of $\mathrm{Zn}$ on root length, number of PR, PRL \% and LR:PRL of $I$. aquatica at the end of 15 days

\begin{tabular}{lcccc}
\hline $\begin{array}{l}\text { Zn } \\
\text { Conc. } \\
\left(\mathbf{m g ~ L}^{-1}\right)\end{array}$ & $\begin{array}{c}\text { Increase in } \\
\text { length of } \\
\text { PR }(\mathbf{c m})\end{array}$ & No. of new PR & PRL \% & LR:PRL \\
\hline Control & $23.77 \pm 2.43^{\mathrm{ab}}$ & $15.67 \pm 2.67^{\mathrm{a}}$ & $53.26 \pm 14.77^{\mathrm{abc}}$ & $5.81 \pm 1.33^{\mathrm{a}}$ \\
0.23 & $39.23 \pm 9.68^{\mathrm{a}}$ & $16.33 \pm 1.33^{\mathrm{a}}$ & $68.88 \pm 6.20^{\mathrm{ab}}$ & $5.00 \pm 0.25^{\mathrm{a}}$ \\
2.27 & $32 \pm 5.04^{\mathrm{ab}}$ & $19.33 \pm 2.40^{\mathrm{ab}}$ & $72.14 \pm 10.90^{\mathrm{a}}$ & $3.49 \pm 0.60^{\mathrm{ab}}$ \\
4.09 & $20.7 \pm 2.92^{\mathrm{b}}$ & $24 \pm 1.15^{\mathrm{b}}$ & $40.09 \pm 11.25^{\mathrm{abc}}$ & $2.92 \pm 0.79^{\mathrm{ab}}$ \\
7.26 & $3.33 \pm 4.08^{\mathrm{c}}$ & $9.67 \pm 1.45^{\mathrm{c}}$ & $38.15 \pm 5.08^{\mathrm{bc}}$ & $0.15 \pm 0.88^{\mathrm{bc}}$ \\
12.71 & $-1.97 \pm 4.22^{\mathrm{c}}$ & $5 \pm 1.73^{\mathrm{cd}}$ & $32.81 \pm 8.88^{\mathrm{c}}$ & $-1.20 \pm 1.69^{\mathrm{c}}$ \\
22.7 & $-4.73 \pm 1.17^{\mathrm{c}}$ & $1.67 \pm 1.20^{\mathrm{d}}$ & $-20.21 \pm 11.40^{\mathrm{d}}$ & $-1.92 \pm 1.05^{\mathrm{c}}$ \\
\hline
\end{tabular}

LR - Lateral roots; PR - Primary roots; PRL \% - percentage of primary roots bearing lateral roots; Values are given as mean $\pm S E$; Values with different superscript letters in the column indicate significant differences at $p<0.05$; '-'Decrease in each parameter with respect to the corresponding initial value

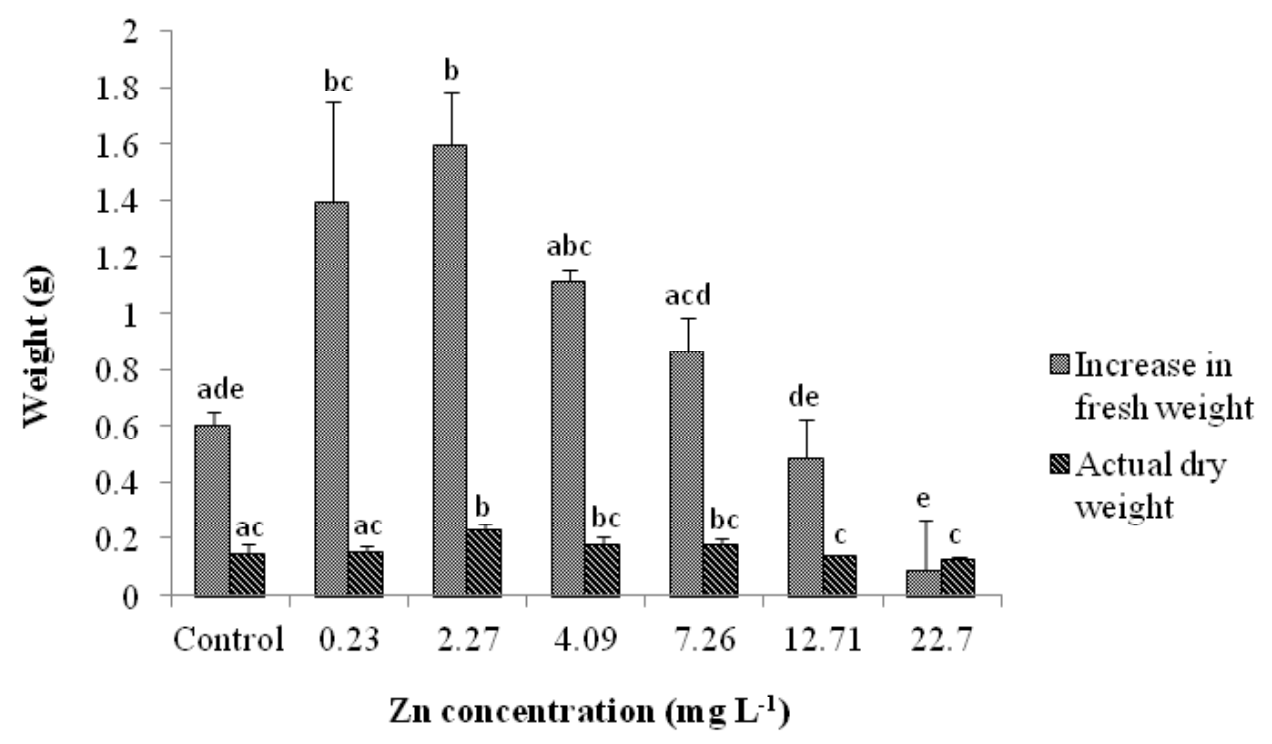

Fig. 3: Effects of Zn on fresh and dry weight of I. aquatica at the end of 15 days exposure; Values are given as mean $\pm S E$; Values with different superscript letters indicate significant differences at $p<0.05$ 
dry weight was not affected at $\mathrm{Zn}$ concentrations of $12.71-22.7 \mathrm{mg} \mathrm{L}^{-1}$, while $0.23-7.264 .09 \mathrm{mg} \mathrm{L}^{-1}$ Zn enhanced growth (Fig. 3 \& 4). On the other hand, one way ANOVA with multiple comparisons by Tukey tests showed that $\mathrm{Zn}$ concentrations of $7.26-22.7 \mathrm{mg} \mathrm{L}^{-1}$ had significant effect on number of new nodes (Fig. 4). There was also decline in increase in shoot length with significant effect at
$22.7 \mathrm{mg} \mathrm{L}^{-1} \mathrm{Zn}$ as revealed by one way ANOVA at $p<0.05$. $\mathrm{Zn}$ being a micronutrient probably enhanced photosynthesis and protein metabolism, thus increasing the growth of plants at low level of $\mathrm{Zn}^{[35]}$. Growth of Sesuvium portulacastrum was enhanced by $\mathrm{Zn}$ concentrations up to $300 \mathrm{mg} \mathrm{kg}^{-136}$. On the other hand, $\mathrm{Zn}$ at $2 \mathrm{mM}$ concentration could decrease shoot height substantially in Phragmites

Table 3: Effects of $\mathrm{Zn}$ on leaf fall, new leaf and leaf area of $l$. aquatica at the end of 15 days

\begin{tabular}{lccc}
\hline $\begin{array}{l}\text { Zn } \\
\text { Conc. } \\
\left(\mathbf{m g ~ L}^{-1}\right)\end{array}$ & $\begin{array}{c}\text { No. of } \\
\text { leaf fallen }\end{array}$ & $\begin{array}{c}\text { No. of } \\
\text { new leaf }\end{array}$ & $\begin{array}{c}\text { Total leaf } \\
\text { area }\left(\mathbf{c m}^{2}\right)\end{array}$ \\
\hline Control & $1.33 \pm 0.33^{\text {ab }}$ & $3 \pm 0^{\text {abd }}$ & $29.30 \pm 4.3^{\mathrm{a}}$ \\
0.23 & $0.33 \pm 0.33^{\mathrm{a}}$ & $2 \pm 0^{\mathrm{ad}}$ & $33.46 \pm 3.65^{\mathrm{a}}$ \\
2.27 & $1.67 \pm 0.33^{\mathrm{ab}}$ & $2.67 \pm 0.33^{\mathrm{abc}}$ & $35.47 \pm 1.36^{\mathrm{a}}$ \\
4.09 & $1.67 \pm 0.67^{\mathrm{ab}}$ & $3.67 \pm 0.33^{\mathrm{bc}}$ & $32.37 \pm 7.03^{\mathrm{a}}$ \\
7.26 & $3 \pm 0.58^{\mathrm{bc}}$ & $2.67 \pm 0.88^{\mathrm{cd}}$ & $25.14 \pm 4.15^{\mathrm{a}}$ \\
12.71 & $3.67 \pm 0.33^{\mathrm{c}}$ & $2.33 \pm 0.33^{\mathrm{d}}$ & $17.72 \pm 2.99^{\mathrm{a}}$ \\
22.7 & $4.33 \pm 0.88^{\mathrm{c}}$ & $0 \pm 0^{\mathrm{e}}$ & $15.65 \pm 1.51^{\mathrm{b}}$ \\
\hline
\end{tabular}

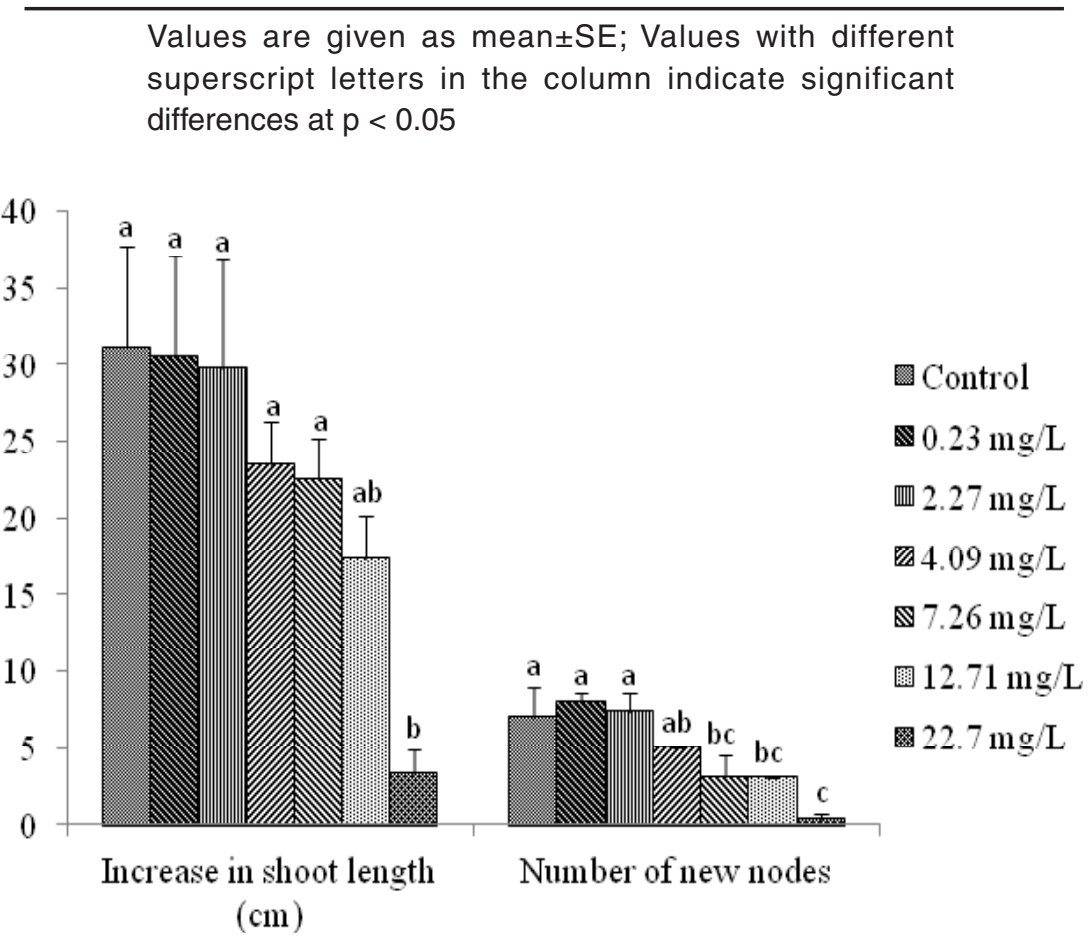

Fig. 4: Effects of $\mathrm{Zn}$ on increase in shoot length and number of nodes in I. aquatica at the end of 15 days exposure; Values are given as mean $\pm \mathrm{SE}$; Values with different superscript letters indicate significant differences at $p<0.05$ 
australis $^{[23]}$. In another study, growth of Hydrilla verticillata was slightly affected by 0.1 and $1 \mathrm{mg} \mathrm{L}^{-1}$ $\mathrm{ZnO}$ nanoparticle treatment for 3 weeks while 1000 $\mathrm{mg} \mathrm{L}^{-1}$ significantly reduced growth of the plant ${ }^{37}$.
Thus, there is a wide variation in response to heavy metals among plants ${ }^{38,39}$.

The results of the present study revealed that $\mathrm{Zn}$ at low concentrations induced new leaf

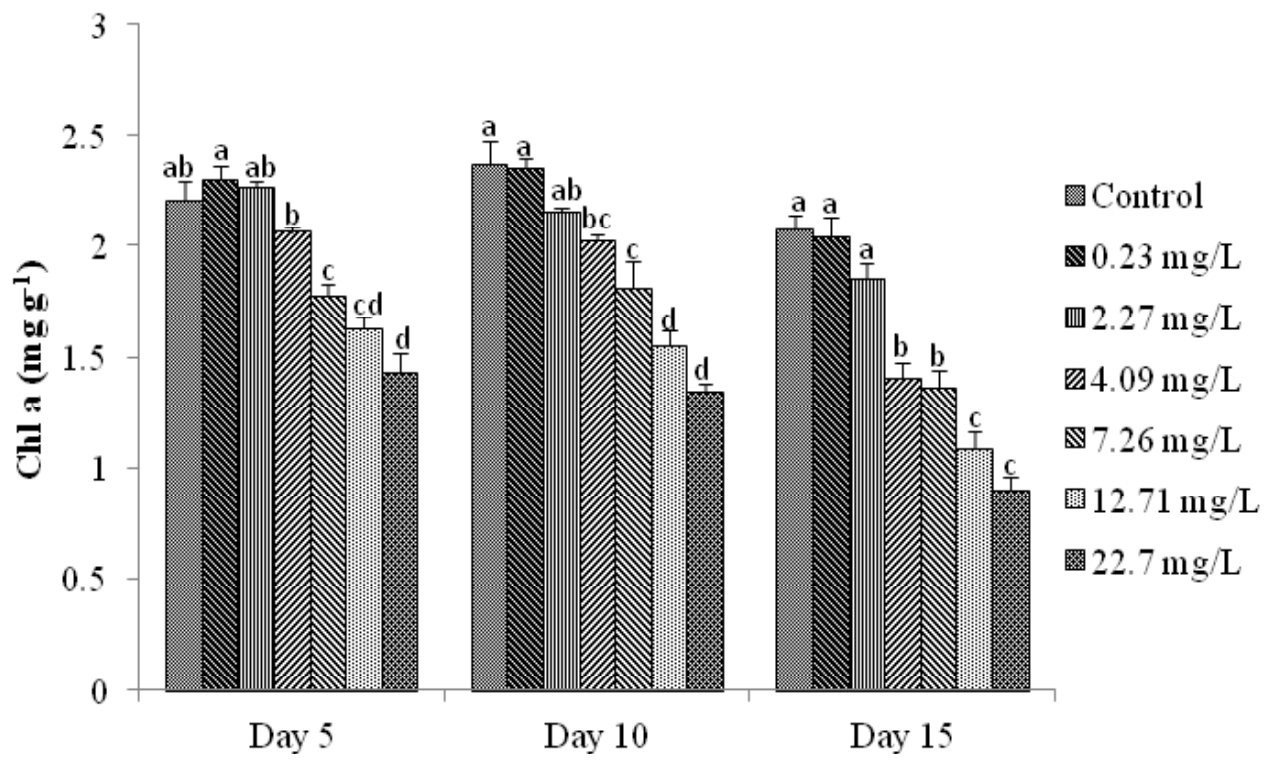

Fig. 5: Effect of $\mathrm{Zn}$ on content of $\mathrm{chl}$ a in leaf of $\mathrm{I}$. aquatica on day 5, 10 and 15 of exposure; Values are given as mean $\pm S E$; Values with different superscript letters indicate significant differences at $p<0.05$

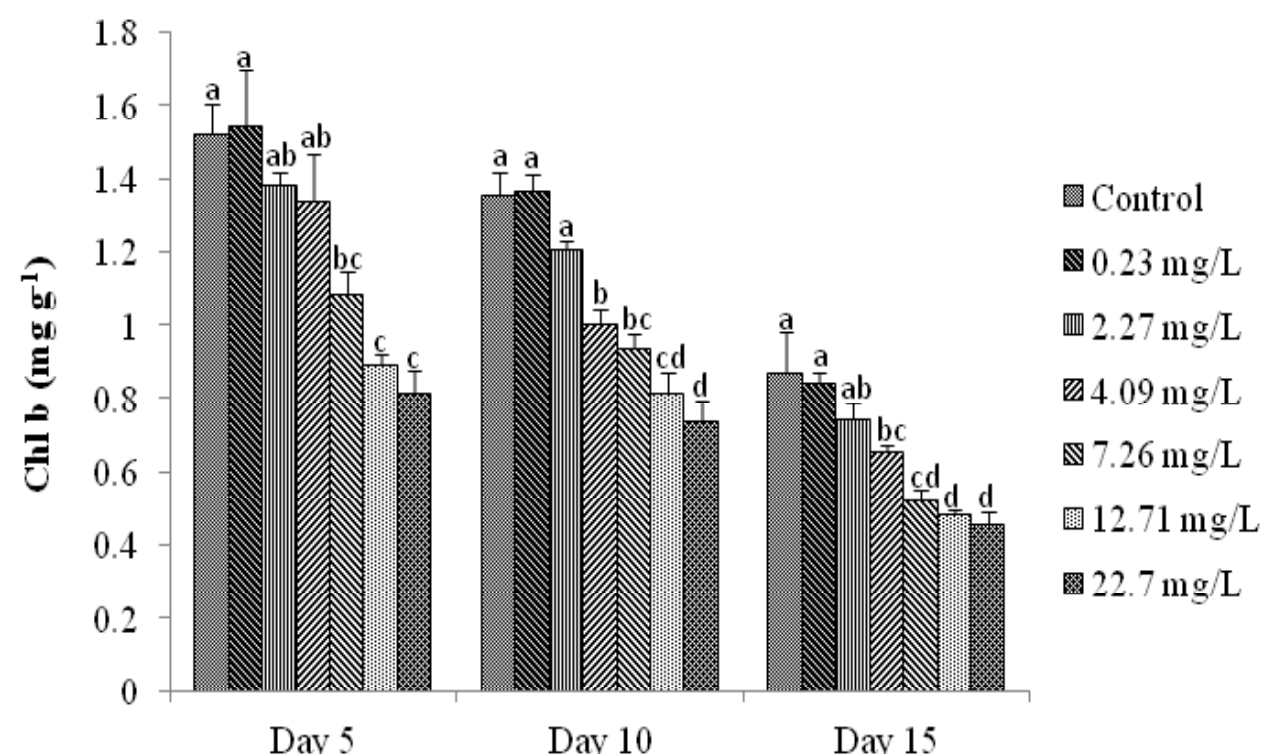

Fig. 6: Effect of $\mathrm{Zn}$ on content of $\mathrm{chl} b$ in leaf of $\mathrm{l}$. aquatica on day 5, 10 and 15 of exposure; Values are given as mean $\pm S E$; Values with different superscript letters indicate significant differences at $p<0.05$ 
development as well as increased leaf area in $I$. aquatica, while at higher concentrations it affected leaf growth (Table 3). One way ANOVA showed significant differences in number of new leaf as well as leaf area among control and $22.7 \mathrm{mg} \mathrm{L}^{-1}$ $\mathrm{Zn}$ treated plants at $p<0.05$. Similar results were also reported in Sesuvium portulacastrum grown in soil amended with $100-600 \mathrm{mg} \mathrm{kg}^{-1} \mathrm{Zn}^{36}$. High concentrations of $\mathrm{Zn}$ also enhanced shedding of older leaf with significantly higher number of leaf fall at 12.71 and $22.7 \mathrm{mg} \mathrm{L}^{-1} \mathrm{Zn}$ from that in control. High $\mathrm{Zn}$ concentration resulted growth retardation and induces leaf senescence by disturbing key metabolic processes such as photosynthetic activity, pigment content and antioxidant systems ${ }^{40,41}$.

The present study revealed that low $\mathrm{Zn}$ concentrations ( 0.23 and $2.27 \mathrm{mg} \mathrm{L}^{-1}$ ) enhanced the content of $\mathrm{chl} \mathrm{a}$ in leaf of $I$. aquatica while it was significantly affected at $7.26-22.7 \mathrm{mg} \mathrm{L}^{-1} \mathrm{Zn}$ concentrations on $5^{\text {th }}$ day of exposure as shown by one way ANOVA at $p<0.05$. A dose and time dependant reduction of chl a content was observed in subsequent days of exposure (Fig. 5). Similar results were also observed in case of $\mathrm{chl} \mathrm{b}$ and total carotene content (Fig. 6 \& 7). Chlorophyll and total carotene content can be considered as effective biomarkers since significant decline was obtained at $7.26 \mathrm{mg} \mathrm{L}^{-1} \mathrm{Zn}$ after $5^{\text {th }}$ day of exposure. In addition, symptoms like leaf yellowing was not observed at this concentration till the end of the experiment. Significant reduction in chlorophyll content with leaf yellowing was also observed in Phragmites australis treated with $1000 \mathrm{mg} \mathrm{L}^{-1} \mathrm{ZnO}$ nanoparticles ${ }^{37}$, although this dose is much higher than the dose of $Z n$ which showed significant effect in the present study. Chl a, Chl b and carotenoid content in Salvinia natans was also significantly reduced by $\mathrm{Zn}$ treatment at the level of $10 \mathrm{mg} \mathrm{L}^{-126}$.

Thus, the results of this study revealed that I. aquatica can successfully be employed in toxicity studies in aquatic ecosystems polluted with $\mathrm{Zn}$ at a threshold limit of about $12 \mathrm{mg} \mathrm{L}^{-1}$ by using root browning, reduction of growth in root and shoot and pigment content as tools for biomonitoring. This plant being resistant to $\mathrm{Zn}$ in terms of survival capacity coupled with its adaptive nature to wide range of habitats, has the prospect of being used in further studies like phytoremediation of $\mathrm{Zn}$ polluted areas.

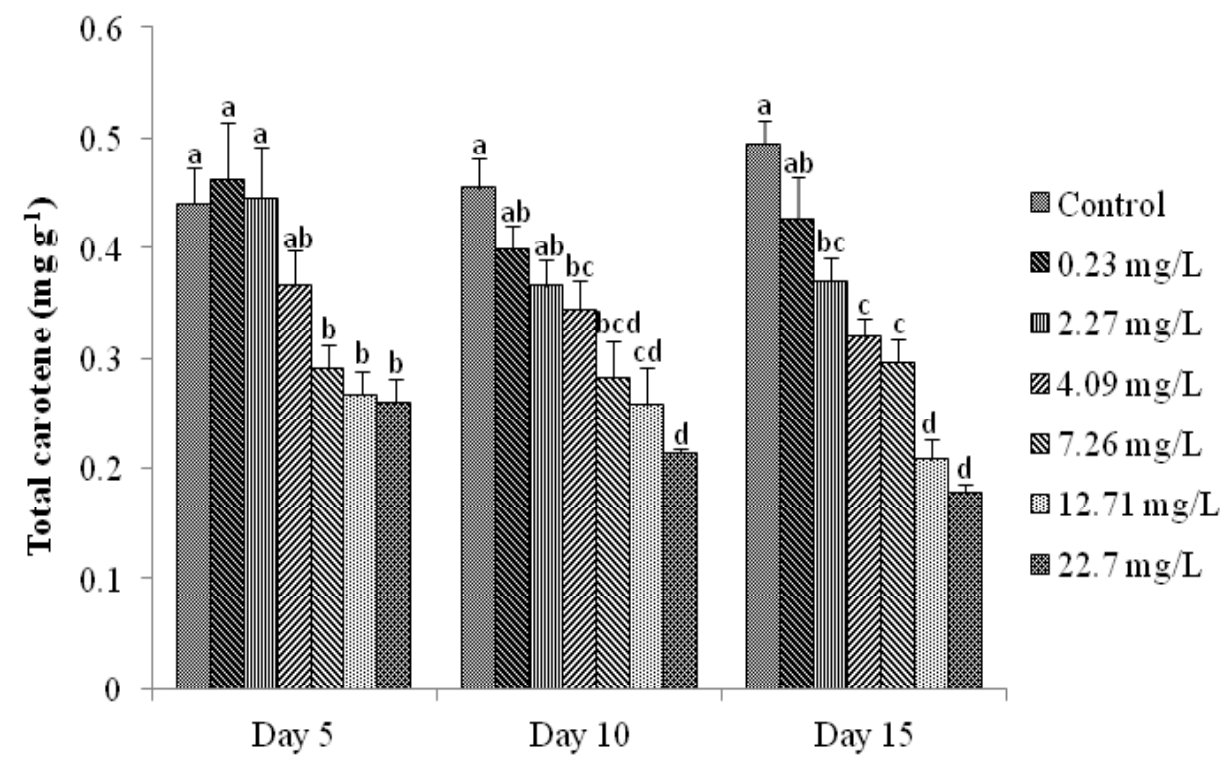

Fig. 7: Effect of $\mathrm{Zn}$ on content of total carotene in leaf of $I$. aquatica on day 5,10 and 15 of exposure; Values are given as mean $\pm \mathrm{SE}$; Values with different superscript letters indicate significant differences at $p<0.05$ 


\section{ACKNOWLEDGEMENT}

LBC would like to thank the University

Grant Commission, New Delhi, India for financial assistance in the form of UGC-BSR Fellowship during the course of the study.

\section{REFERENCES}

1. Kumar, J.I.N., Soni, H. \& Kumar, R.N., Biomonitoring of selected freshwater macrophytes to assess lake trace element contamination: a case study Nal Sarovar Bird Sanctuary, Gujarat, India. Journal of Limnology, 65(1): 9-16 (2006).

2. Kaur, S. \& Mehra, P., Assessment of heavy metals in summer \& winter seasons in River Yamuna Segment flowing through Delhi, India. Journal of Environment and Ecology, 3(1): 149-165 (2012).

3. Das, S., Mitra, A., Zaman, S., Pramanick, P., Chaudhuri, T.R. \& Raha, A.T., Zinc, copper, lead and cadmium levels in edible finfishes from lower gangetic delta, American Journal of Bio-pharmacology Biochemistry and Life Sciences, 3(1): 8-19 (2014).

4. Gupta, S.K., Chabukdhara, M., Kumar, P., Singh, J. \& Bux, F., Evaluation of ecological risk of metal contamination in river Gomti, India: A biomonitoring approach, Ecotoxicology and Environmental Safety, 110: 49-55 (2014).

5. Bagul, V.R., Shinde, D.N., Chavan, R.P. \& Patil, C.L., Causes and impacts of water pollution on rivers in Maharashtra- A review, Research Journal of Chemical and Environmental Sciences, 3(6): 1-4 (2015).

6. Begum, A., Ramaiah, M., Harikrishna, Khan, I. \& Veena, K., Heavy metal pollution and chemical profile of Cauvery River water. E-Journal of Chemistry, 6(1): 47-52 (2009).

7. Subramanian, R., Nesakumari, C.S.A. \& Thirunavukkarasu, N., Status of water quality and heavy metal pollution from Coovum River, Tamilnadu, India. Universal Journal of Environmental Research \& Technology, 3(4): 483-489 (2013).

8. Dhanakumar, S., Solaraj, G. \& Mohanraj, R., Heavy metal partitioning in sediments and bioaccumulation in commercial fish species of three major reservoirs of river Cauvery delta region, India. Ecotoxicology and Environmental Safety, : :145-151 (2015).
9. Anas, A., Jasmin, C., Sheeva, V.A., Gireeskumar, T.R. \& Nair, S., Heavy metals pollution influence in the community structure of Cyanobacteria in nutrient rich Tropical Estuary. Oceanography, 3(1): 1000137, doi:10.4172/2332-2632.1000137 (2015).

10. http://www.atsdr.cdc.gov/substances/ toxsubstance. asp?toxid=54/ (accessed on 29/02/2016).

11. Reddy, M.V., Babu, K.S., Balaram, V. \& Satyanarayan, M., Assessment of the effects of municipal sewage, immersed idols and boating on heavy metal and other elemental pollution of surface water of the eutrophic Hussainsagar Lake (Hyderabad, India). Environmental Monitoring and Assessment, 184: 1991-2000 (2012).

12. Kaur, R., Effect of idol immersion on marine and fresh water-bodies. Advances in Applied Science Research, 3(4): 1905-1909 (2012).

13. Malik, D., Singh, S., Thakur, J., Singh, R.K., Kaur, A. \& Nijhawan, S., Heavy pollution of Yamuna river: An Introspection. International Journal of Current Microbiology and Applied Sciences, 3(10): 856-863 (2014).

14. Aniruddhe, M. A case study of idol immersion in the context of Urban Lake Management. http://parisaraganapati.net/archives/83 (accessed on 24/02/2016).

15. Nagajyoti, P.C., Lee, K.D. \& Sreekanth, T.V.M., Heavy metals, occurrence and toxicity for plants: a review. Environmental Chemistry Letters, 8: 199-216 (2010).

16. Dibofori-Orji, A.N. \& Edori, O.S., Analysis of some heavy metals ( $\mathrm{Pb}, \mathrm{Cd}, \mathrm{Cr}, \mathrm{Fe}, \mathrm{Zn})$ in processed cassava flour (garri) sold along the road side of a busy highway, Archives of Applied Science Research, 7(2): 15-19 (2015).

17. Khumanleima Chanu, H. \& Gupta, A., Necrosis as an adaptive response to copper toxicity in Ipomoea aquatica Forsk. and its possible application in phytoremediation. 
Acta Physiologiae Plantarum, 36; 32753281(2014).

18. Austin, D.F., Water spinach (Ipomoea aquatica, Convolvulaceae) a food gone wild. Ethnobotany Research \& Applications, 5: 123-146 (2007).

19. Prasad, K.N., Shivamurthy, G.R. \& Aradhya, S.M., Ipomoea aquatica, An underutilized green leafy vegetable: A review. International Journal of Botany, 4(1):123-129 (2008).

20. Edi, H.H., \& Ho, B.W.C., Ipomoea aquatica as a vegetable crop in Hong Kong. Econmic Botany, 23(1): 32-36 (1969).

21. Hasan, S.H., Talat, M. \& Rai, S., Sorption of cadmium and zinc from aqueous solutions by water hyacinth (Eichhornia crassipes). Bioresource Technology, 98: 918-928 (2007).

22. Megateli, S., Semsari, S. \& Couderchet, M., Toxicity and removal of heavy metals (cadmium, copper and zinc) by Lemna gibba. Ecotoxicology and Environmental Safety, 72(6): 1774-1780 (2009).

23. Caldelas, C., Dong, S., Araus, J.L. \& Weis, D.J., Zinc isotope fractionation in Phragmites australis in response to toxic levels of zinc. Journal of Experimental Botany, 62(6): 21692178 (2011).

24. Caldelas, C., Araus, J.L., Febrero, A \& Bort, J., Accumulation and toxic effects of chromium and zinc in Iris psuedacorus L. Acta Physiologiae Plantarum, 34: 1217-1228 (2012).

25. Hu, C., Liu, Y., Li, X. \& Li, M., Biochemical responses of duckweed (Spirodela polyrhiza) to zinc oxide nanoparticles. Archives of Environmental Contamination and Toxicology, 64: 643-651 (2013).

26. Hu, C., Liu, X., Li, X. \& Zhao, Y., Evaluation of growth and biochemical indicators of Salvinia natans exposed to zinc oxide nanoparticles and zinc accumulation in plants. Environmental Science and Pollution Research, 21: $732-739$ (2014).

27. Basile, A., Sorbo, S., Conte, B., Cobianchi, R. C., Trinchella, F., Capasso, C. \& Carginale, V., Toxicity, accumulation, and removal of heavy metals by three aquatic macrophytes. International Journal of Phytoremediation, (4): 374-387 (2012).
28. Göthberg, A., Greger, M., Holm, K. \& Bengtsson, B-E., Influence of nutrient levels on uptake and effects of mercury, cadmium, lead in Water spinach. Journal of Environmental Quality, 33:1247-1255 (2004).

29. Lichtenthaler, H.K. \& Wellburn, A.R., Determination of total carotenoids and chlorophylls $a$ and $b$ of leaf in different solvents. Biochemical Society Transactions, 11; 591-592 (1983).

30. Chayapan, P., Krautrachue, M., Meetam, M. \& Pokethitiyook, P., Effects of amenmends on growth and uptake of $\mathrm{Cd}$ and $\mathrm{Zn}$ by wetland plants, Typha augustifolia and Colocasia esculenta from contaminated sediments. International Journal of Phytoremediation, 17: 900-906 (2015).

31. Mishra, V.K. \& Tripathi, B.D., Accumulation of chromium and zinc from aqueous solutions using water hyacinth (Eichhornia crassipes). Journal of Hazardous Materials, 164(2-3): 1059-1063 (2009).

32. Jamal, Q., Durani, P., Khan, K., Munir, S., Hussain, S., Munir, K. \& Anees, M., Heavy metal accumulation and their toxic effects: Review. Journal of Bio-Molecular Sciences, 1(1-2): 27-36 (2013).

33. Shahid, M., Pinelli, E., Pourrut, B., Silvestre, J. \& Dumat, C., Lead-induced genotoxicity to Vicia faba L. roots in relation with metal cell uptake and initial speciation. Ecotoxicology and Environmental Safety, 74(1): 78-84 (2011).

34. Kumar, A., Prasad, M. N. V., Achary, V. M. M. \& Panda, B. B., Elucidation of lead- induced oxidative stress in Talinum triangulare roots by analysis of antioxidant responses and DNA damage at cellular level. Environmental Science and Pollution Research, 20: 45514561(2013).

35. Srivastava, S., Mishra, S., Dwivedi, S., Tripathi, R.D., Tandon, P.K. \& Gupta, D.K., Evaluation of zinc accumulation potential of Hydrilla verticillata. Biologia Plantarum, 53(4): 789-792 (2009).

36. Kalaikandhan, R., Vijayarengan, P., Sivasankar, R. \& Mathivanan, S., The effect of copper and zinc on the morphological parameters of Sesuvium portulacastrum $\mathrm{L}$. 
International Journal of Current Research and Academic Review, 2(3): 105-120 (2014).

37. Song, U. \& Lee, S., Phytotoxicity and accumulation of zinc oxide nanoparticles on the aquatic plants Hydrilla verticillata and Phragmites australis: leaf-type-dependant responses. Environmental Science and Pollution Research, DOI 10.1007/s11356015-5982-5 (2016).

38. Yang, J., Tam, N.F-Y. \& Ye, Z., Root porosity, radial oxygen loss and iron plaque on roots of wetland plants in relation to zinc tolerance and accumulation. Plant Soil, 374: 815-828 (2014).
39. Lin, Y-F. \& Aarts, M.G.M., The molecular mechanism of zinc and cadmium stress response in plants. Cellular and Molecular Life Sciences, 69: 3187-3206 (2012).

40. Nagajyoti, P.C., Lee, K.D. \& Sreekanth, T.V.M., Heavy metals, occurrence and toxicity for plants: a review. Environmental Chemistry Letters, 8: 199-216 (2010).

41. Gomes, M.P., Duarte, D.M., Carneiro, M.M.L.C., Barreto, L.C., Carvalho, M., Saores, A.M., Guilherme, L.R.G. \& Garcia, Q.S., Zinc tolerance modulation in Myracrodruom urundeuva plants. Plant Physiology and Biochemistry, 67: 1-6 (2013). 